\title{
Bladder Irrigation Solution Dosage Form
}

National Cancer Institute

\section{Source}

National Cancer Institute. Bladder Irrigation Solution Dosage Form. NCI Thesaurus. Code C149360.

Sterile liquid preparation intended for irrig ation of the urinary bladder. 